\title{
SETTING UP A BUSINESS ENVIRONMENT \\ TO INTRODUCE A NEW MATERIAL FOR PACKAGING IN INDONESIA
}

\author{
Andina Oktariani")1, Nyayu Lathifah Tirdasari*), Nur Hasanah"), and Dikky Indrawan*) \\ *) School of Business, IPB University \\ Jl. Pajajaran, Bogor 16151, Indonesia
}

\begin{abstract}
Along with the development of consumer behavior that focus on environment, it encourages company to use eco-friendly as attribute to the value preposition on generated product. Although Indonesian consumer aware of environment issues, still they prefer to choose another aspect instead of environmentally friendly on the product that bought by consumer. The aim of this research was to study the factors of environment business that able to support the success of new material development on the environmentally friendly packaging. The method that used in this research is factor analysis. The result of this research show that there are 2 (two) cluster of factors which supported the success of new material development on the environmentally friendly packaging, first factor is advocacy factor towards the innovation of using new material that competitive and logistic infrastructure factor of new material which supported by institutional network. The study is useful for policy maker to organize the right strategy formulation to be implemented on the development of new resource for the environmentally friendly packaging.
\end{abstract}

Keywords: new material, packaging, eco-friendly, factor analysis

Abstrak: Seiring dengan perkembangan perilaku konsumen yang konsen terhadap lingkungan, mendorong perusahaan untuk menggunakan eco friendly sebagai atribut pada value preposition pada produk yang dihasilkan. Walaupun konsumen Indonesia sadar dan memiliki terhadap isu lingkungan, namun konsumen Indonesia masih lebih memilih aspek lain dibandingkan aspek environmental friendly pada produk yang dibeli konsumen. Penelitian ini bertujuan untuk mengkaji faktor-faktor lingkungan bisnis seperti apa yang dapat mendukung keberhasilan pengembangan material baru pada kemasan produk berbasis ramah lingkungan. Metode yang digunakan dalam penelitian ini dengan menggunakan analisis faktor. Hasil penelitian ini menunjukkan bahwa terdapat 2 (dua) klaster faktor untuk mendukung keberhasilan pengembangan material baru pada kemasan produk berbasis ramah lingkungan yaitu, faktor pertama faktor advokasi terhadap inovasi pengunaan materi baru yang berdayasaing serta faktor infrastruktur logistic material baru yang didukung oleh jejaring kelembagaan. Kajian ini berguna bagi para penyusun kebijakan untuk mempersiapkan formulasi strategi yang tepat untuk mengimplementasikan pengembangan bahan baku baru untuk kemasan yang berbasis ramah lingkungan.

Kata kunci: bahan baku terbaru, kemasan, eco friendly, analisis faktor

\footnotetext{
${ }^{1}$ Corresponding author:

Email: andina.oktariani@apps.ipb.ac.id
} 


\section{INTRODUCTION}

Awareness enhancement and consumer concern toward health, food safety and environment issues, which becomes one of the consumer behaviors trends in the last few years in Indonesia. Consumer who realizes about the needed of protection and environmental conservation start to change the consumption pattern and life style, with reducing the consumption that have impact to the environment so that affect the decision to buy eco-friendly product.

Along with the development consumer behavior that concern to the environment, the healthy lifestyle campaign and environmentally friendly business movement increasingly widespread currently. This condition encourages the company to use eco-friendly as attribute to the value preposition on generated product. Segment of society that care to the environment, creating environmentally friendly products more developed from various business field. It becomes a new opportunity for the company who wants to survive in business world competition, with providing environmentally friendly product. Consumer who concern to the environment would prefer to environmentally friendly products and increasing the purchase of ecofriendly product.

Laroche et al. (2002) states that consumer' willingness in buying the eco-friendly product was affected by certain characteristics which is owned by consumer, that is demographics, knowledge, value, attitude and behavior. The result obtained in demographics factor, married woman with one child is a consumer who is more concern to the environment issues. Besides, found that consumer knowledge was not predictor on consumers' willingness to buy environmentally friendly products. While Shrum et al. (1995) study shows that characteristic related to the behavior in buying products such as awareness toward level of products' price which is relatively more expensive, they tend to have high interest toward new product, and tend to have high loyalty to some product brand. It supported by Catalyze Communication (2011) study that shows even though Indonesian consumer still prefer another aspect such as price, loyalty to some brands, friends' recommendation, quality or product freshness to environmentally friendly product. That study found that Indonesian consumer still tend to doubt and skeptical to the company claim or product attribute that state environmentally friendly. Besides that, consumer lifestyle changes that practical and fast also demand product serves which practical and fast. In the last few years, lifestyle factor has become important to be applied extensively and showed the process of consumer decision making about the product. (Chen, 2009).

Description about consumer behavior above encourage the industry have endeavored to develop new packaging environmentally friendly products so that consumer who classified as green consumer have high loyalty ability with buying decision to choose environmentally friendly products. Consumer with high awareness toward environment become potential consumer that also have willingness and decision making in buying the environmentally friendly products.

Therefore, company attributes in producing products such as resource on packaging that confirmed environmentally friendly becomes very important. Ministry of Industry of the Republic of Indonesia (2017) stated that the obstacle of developing environmentally friendly packaging and degradable is most of raw material for degradable plastic still used natural resource that cannot be regenerated and not energy saving so that relatively more expensive. This research raises the issue about what things that become main factor of success that become concern for policy maker in developing new raw material for environmentally friendly products packaging. Therefore, the aim of this research is to study what kind of business environment factors that able to support the industry success in developing new material for environmentally friendly products packaging. The study is useful for policy maker to organize the right strategy formulation to be implemented on the development of new raw material for the environmentally friendly packaging.

\section{METHODS}

This research used quantitative approach with descriptive as type of research. Data type that used in this research is primary data with methods of surveying secondary data from various sources. Data collecting technique that used in this research used questionnaire instrument in Likert scale. The method of respondent taking is non-probability sampling with convenience sampling technique. The respondent in this research is the consumer, in order to see their perspective and consumer point of view as subject who decides to buy some product. Total of consumer respondents that used in the test are 25 respondents. 
The statements that submitted to the respondents in the questionnaire used Likert scale. Likert scale is a tool to measure the attitude in the research. The attitude can be influence or rejection, assessment, like it or not and positivity or negativity toward psychological object. In the research, degree of importance is expected on attribute from every success factor in developing new raw material for the environmentally friendly packaging with Likert scale started from one until five: 1 (Very unimportant);2 (Unimportant); 3 (Quite important); 4 (Important ); 5 (Very important).

This research is done by formulating success aspects in developing new raw material for the environmentally friendly packaging, based on desk study by identifying aspects of new material development on packaging from the input, process and output. The variables of the research are 15 aspects which consist of availability of raw materials; availability of research and technology facilities and instructor; readiness of industry/ business players; level of innovation and product competitiveness; logistic infrastructure; product attributes such as level of confidence, price, quality, various of packaging, serving method; global dynamic and macroeconomics; free market and international market segment; international advocacy and local; government policies and commitments; awareness level of people and industry; institutional network; BPOM certification system; market potency; value-added and economy impact of developing raw materials.

The research used factor analysis to reduce data, that is the process to summarize several variables to be less and named as factor. Factor analysis is used to reduce success key factors of developing new raw material for the environmentally friendly packaging. It is used to identify basic dimensions that able to explain the correlation series of variables. Moreover, factor analysis also identifies smaller new variables, to replace the variable which is not correlated from the series of correlated origin variable (Suliyanto, 2005). Factor analysis can be done with several steps, as follows:

a. Formulation of the problem that raised in the research is to analyze the factors of success key in developing raw material for the environmentally friendly packaging.

b. Creating correlation matrix that useful to test accuracy in factor model. Statistic test that used is Barletts test Sphericity and Kaiser-Mayer-Olkin (KMO) to find out sample adequacy. Kaiser-MayerOlkin (KMO) is the distance comparison index between correlation coefficient and overall partial correlation coefficient. KMO value to be able to do factor analysis is id KMO value $>0,5$.

c. Deciding the total of factor that is needed to represent variables that will be analyzed based on the amount of eigenvalue and percentage of variant total. Only the factor which has same eigenvalue or greater than one which is maintained in the model of factor analysis, while the others is taken out from model.

d. Factor rotation is used to simplify interpretation so that matrix factor which complex in the first place become simpler. The result from factor analysis is matrix factor which contains contribution weight coefficient of variable toward factor or known as factor loading. Rotation in factor analysis can be classified to two, 1. Orthogonal Rotation, which rotate the axis 900 with process rotation orthogonal method, despite Quartimax, Varimax and Equimax. 2. Oblique Rotation, which rotate the axis into right but not 900 with the oblique method rotation process, oblimin, promax, orthoblique and others.

e. Factor interpretation is one by classifying variable which has factor loading minimum 0.4 with factor loading less than 0,4 that taken out from model.

f. Validity model used to find out whether the factors that has been formed based on factor analysis valid. There are ways to do validity test factor analysis result: 1. Divide the beginning sample into two, then compared the result of factor sample one and sample two. If the result does not have much different, it says formed factor is valid. 2. By seeing comparation value between observed correlation and reproduced correlation. It is expected the changes of new correlation matrix not much different with origin correlation matrix.

\section{RESULTS}

Factor analysis is in principle used to reduce data, which is the process of summarizing a number of variables to be smaller and naming them as factors. Factor analysis is used to reduce success key factors of developing new raw material for the environmentally friendly packaging. The variables of the research are 15 aspects which consist of availability of raw materials; availability of research and technology facilities and instructor; readiness of industry/business players; level of innovation and product competitiveness; logistic infrastructure; product attributes such as level of 
confidence, price, quality, various of packaging, serving method; global dynamic and macroeconomics; free market and international market segment; international advocacy and local; government policies and commitments; awareness level of people and industry; institutional network; BPOM certification system; market potency; value-added and economy impact of developing raw materials. In the step of collecting data is done step by step to obtain appropriate factors by testing accuracy in the model.

\section{Kaiser Mayer Olkin}

Kaiser Mayer Olkin KMO value serves as an indicator to see the correlation between variables and to test the accuracy of the factor model with a range of values between 0.5 to 1.0. Research is feasible if the KMO value is more than 0.5 and the analysis process can be continued. In the KMO and Bartlett's Test tables (Table 1), the KMO MSA figures obtained are 0.569. Because the KMO MSA value is greater than 0.5, then the set of variables is mutually correlated. In addition, KMO figures MSA obtained by 0.569 indicates that the measure of accuracy KMO means good enough. In the Bartlett's Test table, you can see the value significance or real level of 0,000 which shows that the process can be continued because the correlation between the variables is significant. The MSA KMO value of 0.569 indicates that there are variables that have an MSA number below 0.5 at the Anti-Image Matrices stage (Table 2) so that the variables with an MSA below 0.5 must be removed, namely, the availability of raw materials, the availability of research facilities and infrastructure and technology, BPOM certification system and readiness of industry / business actors.

With the above analysis, the KMO stage is continued by using 11 variables, the KMO MSA number obtained is 0.718 (Table 3) indicating that the accuracy of $\mathrm{KMO}$ is good. However, at the Anti-Image Matrices stage (Table 4) variables were still found with MSAs below 0.5 , namely the level of public and industrial awareness and global and macroeconomic dynamics. For this reason, the KMO stage was again carried out by eliminating the MSA variable which was still below 0.5 to 9 variables. The KMO MSA results obtained are 0.845 (Table 5) indicating that the measurement of the accuracy of KMO is very good. In the Bartlett's Test table, a significance level of 0,000 can be seen, indicating that the process can be continued because the correlation between the variables is significant.

Table 1. KMO and Bartlett's Test (1)

\begin{tabular}{llc}
\hline Kaiser-Meyer-Olkin Measure of Sampling Adequacy. & & .569 \\
\hline Bartlett's Test of Sphericity & Approx. Chi-Square & 253.212 \\
& df & 105 \\
& Sig. & .000 \\
\hline
\end{tabular}

Table 2. MSA for 15 variables development of raw materials in packaging

\begin{tabular}{llc}
\hline Variables & MSA & \\
\hline Availability of raw materials & 0.411 & Drop \\
Availability of research and technology facilities and infrastructure & 0.453 & Drop \\
National Agency of Drug and Food Control certification system & 0.478 & Drop \\
Product attributes such as level of confidence, price, quality, various of packaging, serving method; & 0.500 & Valid \\
Logistic Infrastructure & 0.539 & Valid \\
Institutional Network & 0.861 & Valid \\
Government Policies and Commitments & 0.587 & Valid \\
Local and international Advocacy & 0.654 & Valid \\
The level of innovation and product competitiveness & 0.500 & Valid \\
Added value and economic impact of developing raw materials & 0.868 & Valid \\
Market Potency & 0.679 & Valid \\
Industry / business readiness & 0.440 & Drop \\
The level of public and industrial awareness & 0.590 & Valid \\
Free market and international market segments & 0.627 & Valid \\
Global dynamics and macroeconomics & 0.679 & Valid \\
\hline
\end{tabular}


Table 3. KMO and Bartlett's Test (2)

\begin{tabular}{llc}
\hline Kaiser-Meyer-Olkin Measure of Sampling Adequacy. & & .718 \\
\hline Bartlett's Test of Sphericity & Approx. Chi-Square & 137.963 \\
& df & 55 \\
& Sig. & .000 \\
\hline
\end{tabular}

Table 4. MSA value for 11 variables development of raw materials in packaging

\begin{tabular}{llc}
\hline Variables & MSA & \\
\hline Product attributes such as level of confidence, price, quality, various of packaging, serving method; & 0.824 & Valid \\
Logistic Infrastructure & 0.758 & Valid \\
Institutional Network & 0.792 & Valid \\
Government Policies and Commitments & 0.787 & Valid \\
Local and international Advocacy & 0.674 & Valid \\
The level of innovation and product competitiveness & 0.828 & Valid \\
Added value and economic impact of developing raw materials & 0.867 & Valid \\
Market Potency & 0.798 & Valid \\
The level of public and industrial awareness & 0.447 & Drop \\
Free market and international market segments & 0.622 & Valid \\
Global dynamics and macroeconomics & 0.440 & Drop \\
\hline
\end{tabular}

Table 5. KMO and Bartlett's Test (3)

\begin{tabular}{llc}
\hline Kaiser-Meyer-Olkin Measure of Sampling Adequacy. & & .845 \\
\hline Bartlett's Test of Sphericity & Approx. Chi-Square & 101.131 \\
& df & 36 \\
& Sig. & .000 \\
\hline
\end{tabular}

\section{Anti-Image Matrices}

Anti-Image Matrices aims to test the partial correlation between variable. In the Anti image Matrices table, a number of numbers forming diagonals marked ' $a$ ' are visible. This sign indicates the MSA magnitude of a variable. Because there is no MSA number below 0.5, the process can continue. The MSA values of the nine variables can be seen in Table 6 .

\section{Extraction}

The next step is to extract a set of factors to form one or more factors. The method used in the extraction process is done to get the value of communality which is the analysis of the main components. In Table 7 Communality can be seen how much the variety of variables can be explained by the factors formed.

Furthermore, the factor extraction process also produces two factor components that are formed based on the value of eigenvalues that are above the value of one. Eigenvalues indicate the relative importance of each factor in calculating the variance of all variables analyzed. Variables with eigenvalues below one is not used in calculating the factors formed. The new factors that are formed can be seen in Table 8 .

Based on the above output two factors can be obtained, each of which has a variance value of 50.241 percent and 17.982 percent so that the total percentage of these two factors is 68.223 percent. So, 68.223 percent of all variables that can be explained by 2 (two) factors formed.

\section{The Factors of Environment Business That Able to Support The Success of New Material Development on The Environmentally Friendly Packaging}

In the results of this study illustrate that the greater the communality of a variable, the more closely related to the factors formed. The results showed that the logistical infrastructure factor of communality value obtained was 0.858 . This means that about 85.8 percent of the variety 
of logistical infrastructure factors can be explained by the factors formed. The logistical infrastructure factor also has the greatest contraction value, meaning that the logistics infrastructure is considered capable of influencing the success of developing new raw materials on packaging. In addition, based on the results of the factor analysis of the nine variables that have been reduced to 2 (two) factors, they are named, the first factor is called the advocacy factor for innovating the use of new materials with energy and the second factor is called the new logistic infrastructure infrastructure factor supported by institutional networks. Naming these factors by characterizing the variables which are in one factor. These factors are:

Factors advocating for innovation in the use of new material that is Competitive

Factors such as the level of innovation and product competitiveness, international and local advocacy, government policies and commitments, market potential, and the added value and economic impact of the development of raw materials are called the advocacy factors for innovations in the use of new materials with engineering. The advocacy factor for innovating the use of new materials that is focused focuses on an active action to create innovations in the development of new raw materials on packaging to improve product competitiveness both locally and internationally. In addition, this factor also means that active actions in creating innovation must be able to provide added value and the impact of economic development in the development of new raw materials on packaging. In this factor also shows that seeing the right market potential is part of supporting innovation in the development of new raw materials on packaging that increase product competitiveness. The implementation of this factor also lies in the government's policy and commitment in creating innovations in the development of competitive new raw material packaging.

Table 6. MSA value for 9 variables development of raw materials in packaging

\begin{tabular}{lc}
\hline Variables & MSA Value \\
\hline Product attributes such as level of confidence, price, quality, various of packaging, serving method; & 0.880 \\
Logistic Infrastructure & 0.766 \\
Institutional Network & 0.722 \\
Government Policies and Commitments & 0.919 \\
Local and international Advocacy & 0.904 \\
The level of innovation and product competitiveness & 0.800 \\
Added value and economic impact of developing raw materials & 0.875 \\
Market Potency & 0.882 \\
Free market and international market segments & 0.851 \\
\hline
\end{tabular}

Table 7. Communalities success factor for the development of new raw materials on packaging

\begin{tabular}{lc}
\hline Variables & MSA Value \\
\hline Product attributes such as level of confidence, price, quality, various of packaging, serving method; & .640 \\
Logistic Infrastructure & .858 \\
Institutional Network & .760 \\
Government Policies and Commitments & .641 \\
Local and international Advocacy & .657 \\
The level of innovation and product competitiveness & .750 \\
Added value and economic impact of developing raw materials & .765 \\
Market Potency & .632 \\
Free market and international market segments & .438 \\
\hline
\end{tabular}


Table 8. Classification of success variables development of environmentally-based food packaging raw materials that are formed

\begin{tabular}{|c|c|c|c|c|}
\hline Factor & Variables & Eigen Value & $\%$ of Variance & Factor Loading \\
\hline \multirow{5}{*}{$\begin{array}{l}\text { Advocating for the } \\
\text { innovation of using } \\
\text { new materials that are } \\
\text { competitive }\end{array}$} & Government policies and commitments & 4.522 & 50.241 & .710 \\
\hline & Local dan International International & & & .810 \\
\hline & $\begin{array}{l}\text { The level of innovation and product } \\
\text { competitiveness }\end{array}$ & & & .865 \\
\hline & $\begin{array}{l}\text { Added value and economic impact of } \\
\text { developing raw materials }\end{array}$ & & & .748 \\
\hline & Market Potency & & & .758 \\
\hline \multirow{5}{*}{$\begin{array}{l}\text { New material } \\
\text { logistics infrastructure } \\
\text { supported by } \\
\text { institutional networks }\end{array}$} & $\begin{array}{l}\text { Product attributes such as level of confidence, } \\
\text { price, quality, various of packaging, serving } \\
\text { method; }\end{array}$ & 1.618 & 17.982 & .587 \\
\hline & Logistic Infrastructure & & & .891 \\
\hline & Institutional Network & & & .871 \\
\hline & Free market and international market segments & & & .641 \\
\hline & Total of variance & & 68.223 & \\
\hline
\end{tabular}

The advocacy factor for innovating the use of new material that has the highest loading factor is the level of innovation and product competitiveness with a value of 0.865 which shows the level of innovation and product competitiveness has a very strong correlation value. The level of innovation and product competitiveness reflects how the development of new raw materials results in packaging innovations to increase packaging daytime power so that environmentally friendly packaging is the top of mind in consumers' minds not only labeled as environmentally friendly. While the Government's policies and commitments have the smallest factor loading value in the advocacy factor for innovating the use of new competitive materials with a value of 0.701 . This shows that policy support and government commitment are factors that must be improved to be able to create innovations in the development of new raw materials on competitive packaging. Government policies and commitments can be first, continuing various policies and initiatives to support the use of new raw materials on packaging; secondly, building new business configurations and encouraging the ease of licensing for the benefit of projects or facilities in the fulfillment of new raw materials for packaging; third, better use of market-based instruments. Specifically use taxes to encourage the production and consumption of more environmentally friendly activities and products; fourth, continuing to build capacity, especially between provincial and district authorities to implement relevant laws and regulations; and fifth, ensuring coherence between sectoral development goals and sustainable development goals.
New material logistics infrastructure factors supported by institutional networks

Factors such as logistics infrastructure, product attributes which include the level of trust, price, quality, packaging, mode of presentation; free markets and international market segments, as well as institutional networks are called new material logistics infrastructure factors supported by institutional networks. New material logistics infrastructure factors supported by institutional networks focus on availability, speed of fulfillment, and the cost of distribution in the development of raw materials on packaging to be an important component in the logistics infrastructure that needs institutional network support because it relates to supply chain management. In addition, the infrastructure factor for new logistics materials also needs easy access to free markets and international market segments to obtain quality and competitive raw materials to produce product attributes that can increase consumer confidence in environmentally friendly packaging, quality, competitive prices, packaging and presentation methods. innovative.

The new logistical infrastructure factor supported by institutional network which has the biggest loading factor is logistical infrastructure, which is 0.891 . This shows that the assessment has a strong correlation with the factor of new material logistics infrastructure supported by institutional networks and has an influence on the development of new raw materials on environmentally friendly packaging. The logistics infrastructure will 
determine how quickly the company is able to provide new packaging raw materials that are approaching the industry, and how quickly the company is able to fulfill orders from consumers, and how efficient is the cost of distributing products from the company's factories or warehouses to end customers. Then, the institutional network has a factor loading value that is not too much different from the rating that is equal to 0.871 . This means that the institutional network variable is a very influential attribute in the new material logistics infrastructure factor supported by the institutional network. Institutional networks are important to create efficient supply chain management.

Product attributes (level of trust, price, quality, packaging, manner of presentation) are part of the new material logistics infrastructure factors supported by institutional networks that have the smallest factor loading values, with a value of 0.587 . Product attributes (level of trust, price, quality, packaging, mode of presentation) are things that support the creation of new material logistics infrastructure factors supported by institutional networks. Product attribute factor is the goal to achieve new material logistics infrastructure supported by institutional networks

\section{Managerial Implications}

A good business environment greatly influences the success of a business development, including the development of new materials in environmentally friendly product packaging. This study provides an illustration that business environmental factors such as logistics management that lead to infrastructure readiness are important points that must be prepared in supporting the development of a new material in creating added value for a package. This research also shows that support in the form of advocacy for innovation at the national and international levels is an important key in the successful development of a product, furthermore the government's commitment to policies that support innovation, especially in the development of environmentally friendly packaging, has a high portion where both will create and grow. market potential and added value that have an impact on the community's economy. Advocacy and government commitment are important in the development of environmentally friendly packaging, it is assumed that some other producers who supply other packaging raw materials will be significantly affected.
This research also illustrates that the logistics management built must have a strong institutional network so that supply chain management in developing new packaging materials can be carried out efficiently. The success of developing new raw materials for packaging also requires high credibility to build a level of public awareness in the use of environmentally friendly packaging. The components of packaging quality and appearance are important in attracting the market. For this reason, the contribution of this research can provide initial enrichment regarding factors that can be considered in creating a business innovation in a package.

\section{CONCLUSIONS AND RECOMMENDATIONS}

\section{Conclusions}

In this study concluded that there are nine variables that are able to influence the successful development of new raw materials on packaging. The results showed that the logistical infrastructure factor of communality value obtained was 0.858 . This means that about 85.8 percent of the variety of logistical infrastructure factors can be explained by the factors formed. The logistical infrastructure factor also has the greatest extraction value, meaning that logistical infrastructure is considered the main factor that can influence the success of developing new raw materials on packaging. Based on the results of the factor analysis of the nine variables that have been reduced to 2 (two) factors named, namely, the first factor is called the advocacy factor for innovating the use of new materials and the second factor is called the new logistic infrastructure infrastructure factor supported by institutional networks. The advocacy factors for innovating the use of new materials that consist of energy consist of the level of innovation and product competitiveness, international and local advocacy, government policies and commitments, market potential, as well as the added value and economic impact of developing raw materials. The advocacy factor for innovating the use of new material which has the highest loading factor is the level of innovation and product competitiveness with a value of 0.865 . New material logistics infrastructure factors supported by institutional networks consist of logistics infrastructure, product attributes which include the level of trust, price, quality, packaging, mode of presentation; free market and international 
market segments, and institutional networks. The new logistical infrastructure factor supported by institutional network which has the biggest loading factor is logistical infrastructure, which is 0.891 .

\section{Recommendations}

Limitations This study has the object of observation focused only on 25 consumer respondents who anyone can provide information either accidentally or accidentally meet with researchers, can be used as a sample, if seen by people who provide such information is suitable as a data source (Sekaran 2006). Therefore, caution is needed in adjusting product characteristics to the characteristics of the research object to apply this study to different contexts. This is done so that there is no bias in the results of testing that can have an impact on the errors in understanding the implications of research.

\section{REFERENCES}

Chen MF. 2009. Attitude Toward Organic Foods Among Taiwanese as Related to Health Consciousness, Environmental Attitudes and the Mediating Effects of a Healthy Lifestyle. British Food Journal 111 (2): 165-178.

Catalyze Communication. 2011. Emerging Opportunities For Green Product in Indonesia: A National Survey of Consumer Attitudes. Komunigrafik.

Chong SC. 2005. KM Critical success factors : A Comparison of Pereceived Importance versus
Implementation in Malaysian ICT Companies. http://search.proquest.com/docview/215654405 /1354D9CF7952FE496D7/ 1?accountid=32819 [1 Maret 2020]

Johan J, Agneta M, Annika N. 2010. Green consumer behavior: determinants of curtailment and ecoinnovation adoption, Journal of Consumer Marketing 27(4):358 - 370.

Kementerian Perindustrian Republik Indonesia. 2017. Begini Prospek dan Kendala Pengembangan Industri Plastik Nasional. https://economy. okezone.com/read/2017/05/08/320/1686253/ begini-prospek-dan-kendala-pengembanganindustri-plastik-nasional. [1 April 2020].

Kotler P. 2000. Marketing Management. NY: McGraw Hill.

Laroche M., Bergeon J, Forleo GD. 2002, Targetting Consumers Who Are Willing to Pay More For Environmentally Friendly Products, Journal of Consumer Marketing 18(6): 503-520.

Sekaran U. 2006. Research Methods for Business (Metode Penelitian untuk Bisnis). Jakarta: Edisi empat buku 1. Salemba Empat.

Shrum LJ, McCarty, John AL, Tina M. 1995. Buyer characteristics of the green consumer and their implications for advertising, Journal of Advertising; Summer.

Suliyanto. 2005. Analisis Data dalam Aplikasi Pemasaran. Bogor: Ghalia Indonesia.

Windarti. 2010. Analisis Faktor-Faktor Kunci Kesuksesan Implementasi Manajemen Pengetahuan pada PT Unilever Indonesia Tbk [Skripsi]. Bogor: FEM-IPB. 